\title{
An Experimental Study of Chinese English Major Students' Listening Anxiety of Classroom Learning Activity at the University Level
}

\author{
Shengli Wang \\ School of Foreign Studies, Henan Agricultural University, Zhengzhou, China \\ Email: victor@henau.edu.cn
}

\begin{abstract}
Foreign language anxiety is one of the best predictors in accounting for individual differences in language learning success in SLA, and that it is proved to be one of the most essential and influential affective factors. The present study adopts English listening tests and questionnaire to conduct a survey on English listening classroom anxiety with 125 English majors as its subjects. The results show that there exist certain negative correlations both between English listening classroom anxiety and listening achievement. This thesis investigates the influence anxiety has on listening comprehension, explores the potential sources of foreign language listening anxiety, and puts forward some coping strategies from various aspects such as learners' psychology, teaching techniques, etc. in a hope to create a low-anxiety classroom atmosphere, and help to improve students' listening performance and proficiency in a most favorable affective state.
\end{abstract}

Index Terms — anxiety, listening, English teaching, strategies

\section{INTRODUCTION}

Listening is one of the most important skills for a student to learn in order to communicate effectively and in a mutually satisfying manner. Unfortunately, listening and speaking are the weakest points of most English learners of all the five skills in China. Poor listening ability results from many factors, such as insufficient emphasis on listening by the whole society, immature teaching methodologies, ineffective listening strategies, and students' lack of vocabulary, but the increasingly important one is that anxiety, an affective factor in listening comprehension, plays a very important role because the anticipation of foreign language use in receiving information can provoke anxiety. Listening comprehension is "highly anxiety-provoking if the discourse is incomprehensible" (Young, 1992). Therefore, anxiety has gradually been a focus of research in the area of listening comprehension and it is a "variable that must be respected in teaching and accounted for in research" (Young, 1999). Listening anxiety of Chinese English major students in the college classroom learning activity is researched in this thesis to investigate the influence of anxiety on listening comprehension and to discuss further the potential sources of English listening classroom anxiety and suggest possible coping strategies.

\section{Methodology}

\section{A. Subjects}

The subjects chosen for this study are 131 second-year English majors from four classes in Grade 2008 at Henan Agricultural University (HAU) during an autumn semester. Six subjects failed to follow the instructions and their data were excluded, leaving a total sample of 125. There are about 33 students in each of four classes and the gender ratio between male and female is about 1:7. All of them have learned English for at least 7 years before entering college. After 3 to 4 semesters at HAU, they will be required to sign up for CET-6(College English Test, Band 6), TEM-4(Test for English Majors, Grade 4) and TEM-8(Test for English Majors, Grade 8). Only TEM-8 is not compulsory. They are willing to cooperate because they want to know how to cope with language anxiety and improve their 1istening ability.

\section{B. Instruments}

The Foreign Language Listening Anxiety Scale (FLLAS) (See Appendix II), the listening proficiency test --TOEFL (Test of English as a Foreign Language) and the subjects' personal background information such as sex, age, major, and their scores in the last semesters' listening exams in college are employed in the study. The subjects are required to put down their students' ID card numbers so that the researcher can easily get their personal background information. The questionnaire is in Chinese for the sake of convenience and time-saving. The FLLAS is used to measure the level of their listening anxiety. Two TOEFL listening tests and scores of students' listening examinations gained from their records for undergraduate students of HAU are used to check the participants' English listening proficiency.

1. Foreign Language Listening Anxiety Scale (FLLAS)

In this study, the researcher chooses the main part of Kim's (2000) English version of FLLAS which is based on the 
FLLAS designed by Horwitz et al in 1986. The Foreign Language Classroom Anxiety Scale designed by Horwitz et al in 1986 is one of the most popular instruments used in the language anxiety research. The scale is a self-report measure of language learner's feelings of anxiety in the foreign language classroom. The scale has 35 items and 5-point likert-type scales are used. According to Horwitz (1986), the internal consistency is 0.93 based on Cronbach's coefficient alpha and test-retest reliability over a period of eight weeks is $r=0.83(p<0.001)$. Therefore, the scale is "an adequately reliable and valid measure" (Kim, 2000). The purpose of this scale is to measure the general language anxiety as a specific reaction to foreign language learning. Listening anxiety as a language anxiety accompanied by listening process has its own characteristics. Therefore, some researchers, such as Elkhafaifi (2005), Zhou (2003) and Kim (2000), studying listening anxiety tend to work out their own scales on the basis of the FLLCAS. Kim (2000) uses her own version of Foreign Language Listening Anxiety Scale in her dissertation under the supervision of Horwitz, E.K. To develop the new instrument, Kim follows the guidelines of Gable and Wolf and De Vellis. The adapted second language version of Wheeless' Receiver Apprehension Test and the Foreign Language Reading Anxiety Scale by Saito, Horwitz and Garza (1999) are also good sources for addition to items. A five point Likert Scale has been widely used in instruments measuring opinions, beliefs and attitudes, so it was chosen in the research. It ranges from 1) "strongly disagree" to 5) "strongly agree". A student's endorsement in 1) "strongly disagree" is equated with a numerical value of one; 2) "disagree" is two; 3) "neither agree nor disagree" is three; 4) "agree" is four; and 5) "strongly agree" is five. After the deletion of 8 items, an alpha of 0.93 and 33 items remained in the final form of the instrument. Therefore, as a scale, it is highly reliable. In the study of HAU English majors' listening anxiety, the researcher uses Kim's English version, adapts, deletes and adds some items (Items 3, 14, 20, 21, 29, 30, 31, 32, 33, 34 and 35) for his own research purposes. The final version has 35 items and 3 categories: tension and worry over English listening (Items 2, 3, 4, 9, 10, $12,13,14,16,17,19,20,21,22,24,31,32,33,34$, and 35), lack of confidence in English listening (Items 6, 7, 8, 13, 18, 25, and 27), concern about insufficient prior knowledge( Items 1, 5, 11, 15, 23, 29, and 30) and some items (Items 6, $21,23,25,27,31$, and 35) are negatively worded so that the participants would not fall into a pattern of marking only one side of the rating scale. For each subject, an anxiety score is derived from summing his or her ratings of those items in the questionnaire. A high score represents high anxiety in the English classroom. According to the results of FLLAS, the 125 students are classified into three groups: HI-ANX(High Anxiety), AVE-ANX(Average Anxiety) and LO-ANX(Low-Anxiety) in order to compare their scores of semester listening examinations and TOEFL listening tests.

TABLE 1

CATEGORIES AND ITEMS OF FLLAS

\begin{tabular}{|c|c|c|c|}
\hline \multicolumn{3}{|c|}{ FLLAS } \\
\hline Categories & $\begin{array}{c}\text { Tension and Worry over English } \\
\text { Listening }\end{array}$ & $\begin{array}{c}\text { Lack of Confidence in } \\
\text { English Listening }\end{array}$ & $\begin{array}{c}\text { Concern about Insufficient Prior } \\
\text { Knowledge }\end{array}$ \\
\hline Items & $\begin{array}{c}\text { Items 2, 3, 4, 9, 10, 12, 13, 14, 16, 17, } \\
19,20,21,22,24,31,32,33,34, \text { and 35 }\end{array}$ & $\begin{array}{c}\text { Items 6, 7, 8, 13, 18, 25, } \\
\text { and 27 }\end{array}$ & Items 1, 5, 11, 15, 23, 29, and 30 \\
\hline
\end{tabular}

2. Students' personal information and TOEFL Listening Tests

The students' ID card numbers can clearly and officially elicit their basic demographic information, including name, sex, age, birth place and various records such as the first and second semester's listening grades. The research purpose is explained and the privacy of the participants is ensured to be respected by the researcher. According to the English Teaching Syllabus for English Majors of Universities (2000), the English proficiency of the second-year English major after two semesters' study should meet Grade Three. Therefore, the researcher does not use TEM-4, which is an authoritative proficiency test for English majors after 3 to 4 semesters learning. TOEFL, a Test of English as a Foreign Language, is to evaluate the English proficiency of people whose native language is not English. The test uses a multiple-choice format to measure the ability to understand North American English. The test consists of three sections: listening, structure/written expression (i.e. grammar) and reading comprehension. Listening Comprehension is to measure the ability to understand English as it is spoken in North America. Most students taking this examination must achieve a certain score to enter an institution abroad of higher learning. Therefore, TOEFL is used in the study to more appropriately evaluate the subjects' listening proficiency. The listening proficiency test for the second-year English majors of HAU is the listening parts of the TOEFL tests in January and October 2009.

3. Data Collection

In autumn, 2009, the questionnaire and TOEFL listening test were carried out at HAU and the data of the study were collected. The instructions about how to fill in the questionnaire were explained carefully to them. First, the participants were told the purpose of the research. Second, the listening tests and instructions were carried out in language labs. The participants were informed to start with the TOEFL listening questions. They were also guaranteed that the results and personal information would not be publicized and had nothing to do with their final-term listening test score. Seventy minutes later the test papers were collected. After the listening tests, the questionnaire was given to each participant, and it took about 20 minutes to finish. Third, the data of each class were collected separately and given to the researcher. 131 copies of questionnaires and test papers were collected. Six of them were not counted because the participants failed to follow the instructions completely.

4. Data Analysis Procedure

FLLAS is based on a Likert-type scale with five possible responses to each of the questions. The scale ranges from 1 
(Strongly Disagree) to 5 (Strongly Agree). The answer indicating the highest degree of anxiety receives five points, whereas the answer indicating the least anxiety is one point. The quantitative analysis includes descriptive statistics, reliability analysis, correlation analysis and One-way ANOVA which are provided by SPSS. In order to summarize the participants' background information and responses to the questionnaire, descriptive statistics (mean, SD, maximum, minimum, frequency distribution of the variables) were computed for each item. The negative worded items were firstly recoded and the mean of two TOEFL listening scores and the sum of anxiety scores for each participant were computed. The relationship of the two scores -- the mean of first and second semester's listening examination scores and that of the two TOEFL listening test scores and the relationship between listening proficiency and listening anxiety were tested by the correlation analysis.

\section{RESULTS AND DISCUSSION}

\section{A. Scale Analysis of the FLLAS and Reliability of the FLLAS}

The FLLAS is comprised of 35 items scored on a five-point scale with a theoretical range of 35 to 125 . After the relatively few negatively worded items being recoded, a higher score indicates a higher level of listening anxiety and a lower score indicates a lower level of listening anxiety. In this study, the total scores ranges from 72 to 137 with a mean of 101.38 and a standard deviation of 14.30. A mean scale score is also computed. On the basis of a 5-point format, the mean score is 2.95 indicating a slightly elevated level of listening anxiety. The three categories of FLLAS: tension and worry over English listening (Items 2, 3, 4, 9, 10,12, 13, 14, 16, 17, 19, 20, 21, 22, 24, 31,32, 33, 34, and 35), lack of confidence in English listening (Items 6, 7, 8, 13, 18, 25, and 27), concern about the insufficient prior knowledge ( Items 1, 5, 11, 15, 23, 29, and 30) receive different scores. The first category ranges from 48 to 86 with a mean of 64.19 and a standard deviation of 8.26. The mean scale score of this category is 3.01. The second category ranges from 10 to 27 with a mean of 19.83 and a standard deviation of 4.28 . The mean scale score of this category is 2.81 . The third category ranges from 14 to 31 with a mean of 22.04 and a standard deviation of 4.37 . The mean scale score of this category is 3.04. The result shows anxiety due to the first and third categories are roughly equal. Anxiety due to lack of confidence for the participants is less than the anxiety caused by the insufficient prior knowledge or tension and worry over English listening.

TABLE 2

DESCRIPTIVE STATISTICS OF FLLAS

\begin{tabular}{|c|c|c|c|c|c|}
\hline & Listening anxiety & Listening worry & Confidence & Prior knowledge & Valid N(listwise) \\
\hline $\mathrm{N}$ & 131 & 131 & 131 & 131 \\
Minimum & 72.00 & 48.00 & 10.00 & 14.00 & 31.00 \\
Maximum & 137.00 & 86.00 & 27.00 & 22.0352 \\
Mean & 101.3782 & 64.1927 & 19.8329 & 4.37217 \\
Std. deviation & 14.29813 & 8.26171 & 4.27611 & \\
\hline
\end{tabular}

As a result of SPSS analysis, Cronbach's coefficient alpha is 0.841 for the FLLAS and Cronbach's coefficient alpha of the three categories are 0.702 for the category about the tension and worry over English listening and 0.637 for the category about lack of confidence in English listening and 0.650 for the category about concern about insufficient prior knowledge. The results are acceptable because Cronbach's coefficient alpha of the overall scale is higher than 0.80 and Cronbach's coefficient alpha of the subcategories is higher than 0.60 . Therefore it is a scale with high reliability and the items in the scale are consistent.

TABLE 3

RELIABILITY OF THE FLLAS

\begin{tabular}{|c|c|}
\hline \multicolumn{2}{|c|}{ RELIABILITY OF THE FLLAS } \\
\hline Scale & Cronbach's coefficient alpha \\
\hline FLLAS & 0.841 \\
\hline Tension and Worry over Listening & 0.702 \\
\hline Lack of Self Confidence & 0.637 \\
\hline Concern about The Insufficient Prior Knowledge & 0.650 \\
\hline
\end{tabular}

\section{B. Worries and Tension over Foreign Language Listening}

Anxiety caused by tension and worries over English listening includes Items 2, 3, 4, 9, 10, 12, 13, 14, 16, 17, 19, 20, $21,22,24,31,32,33,34$ and 35. The means of Items 2, 3, 4 and 9 show that the participants suffer higher anxiety in those situations. $51.8 \%$ of the participants report that they get nervous if a listening passage is read only once during the English listening exams. $70.3 \%$ of the participants report that it is difficult to understand English with an accent and none disagree or strongly disagree with it. When a person speaks English very fast, $69.4 \%$ of them worry that they might not understand all of it. While listening to English, $73.1 \%$ of the participants feel more relaxed if there are some visual clues (e.g. with pictures, TV programs, speakers with facial expressions). Accent is one of the characteristics of the spoken language, but since most materials used in listening classes are usually Standard English, once the students are exposed to English with an accent or dialects, they will likely feel more anxious. The best way to handle this anxiety 
is to make an extra-curriculum listening plan and listen to more authentic English. As a foreign language learner, he usually can not control the velocity of the input especially during listening tests and lectures. Even in the interactive listening, it is not easy for Chinese students to control the speaker's speaking speed. In addition, they are too cautious and polite and they dread losing face before peers. To avoid this occurrence the students should make use of the strategies to ask for repetition and clarification. With regard to the visual cues, visual methods in listening classes are always limited because of lack of facility; the listening materials are often given without any visual support except the question items. Therefore in the interactive listening, a listener can use visual cues to help understand what the speaker means; but in listening tests, it is impossible to get visual cues for help. This is perhaps one reason why some students do not feel anxious if they have some visual cues. In other situations of the interactive listening, such as telephone conversations or attending lectures, $18.1 \%$ of the participants report that they feel anxious in telephone conversations but $61.3 \%$ of them feel anxious when listening to a lecture. The reason may be that telephone conversations are carried out with some familiar greetings, but lectures can cover any topics and the listener cannot control the speed of the speech; therefore they make listeners more anxious. As to listening class anxiety, Item 32 shows that there are only $7.2 \%$ of the participants who do not often feel like going to their listening classes; Item 33 shows that $23.7 \%$ of the participants report that they often daydream in listening classes; $19.5 \%$ of them worry that they will fail in listening tests; $26.9 \%$ of the participants report that they do not feel nervous at all while taking semester listening exams. To sum up, listening anxiety experienced by students in listening class is not very high to most of the participants. But in some interactive listening situations, they suffer severer anxiety.

\section{Correlation Analysis}

The TOEFL listening scores which represent the listening proficiency is significantly and positively correlated with the scores of two semesters' listening exams. This result means the changing direction of the TOEFL listening mean scores is consistent with the changing directions of two semesters' listening exam scores. That is to say, those who have higher scores in the two semesters' listening exams usually score high in the TOEFL listening tests. Therefore, the mean of the TOEFL listening scores can be accepted as a method to test the listening proficiency of the participants, although it only represents the non-interactive listening proficiency. According to the mean of the subjects' TOEFL listening scores and that of two semesters' listening exam scores, the 125 students were divided into three groups: HI (the group of high grades) of 29 students who got more than 80 scores, AVE (the group of average grades) of 83 students who got between 65 and 85 scores and LOW (the group of low grades) of 13 students who got below 65 scores.

According to the results of the FLLAS, the 125 students were classified into three groups. First, we calculated the group's mean for all the questions $(\mathrm{M}=3.22)$, and then determined the degree to which students deviated from the mean. The deviation of the highest score (i.e. the most anxious student) from the mean is +0.8 , and the deviation of the lowest score from the mean is -0.76 . So those students that score between +0.4 and -0.38 standard deviations from the mean were identified as AVE-ANX; and those with standard deviations below -0.38 were identified as LO-ANX; and the students with standard deviations over +0.4 were identified as HI-ANX. Table 4 presents the number and percentage of students in each FLLAS category and mean anxiety level and range of each identified group.

TABLE 4

FLLAS CATEGORIES

\begin{tabular}{|c|c|c|c|c|}
\hline Category & Number & Percentage & Mean & Range \\
\hline LO-ANX & 20 & $16 \%$ & -0.47 & $-0.76 \sim-0.39$ \\
\hline AVE-ANX & 91 & $73 \%$ & +0.244 & $-0.38 \sim+0.4$ \\
\hline HI-ANX & 14 & $11 \%$ & +0.516 & $+0.41 \sim 0.8$ \\
\hline
\end{tabular}

The data computerized in the SPSS imply that the listening proficiency of second-year English majors is negatively correlated with the listening anxiety at the 0.00 level, which further confirms the previously-conducted researches(Aida, 1994; Cheng et al, 1999; Horwitz et al., 1986; MacIntyre \& Gardner, 1991; Kim, 2000; Zhou, 2003 and Chen, 2004 ; Elkhafaifi, 2005): when the listening anxiety goes up, the proficiency will go down, and vice versa (See Table 5). It can be concluded that FLLAS has a significant but debilitating correlation with English listening achievement ( $\mathrm{r}=-0.392)$, which indicates that anxiety does affect listening proficiency negatively.

TABLE 5

CORRELATION BETWEEN THE LISTENING PROFICIENCY AND FLLA

\begin{tabular}{|c|c|c|c|}
\hline & & Listening proficiency & FLLA \\
\hline Listening proficiency & Pearson Correlation Sig. (2-tailed) N & 1.000 & $-0.392 * *$ \\
& & - & .000 \\
& & 125 & 125 \\
\hline FLLA & Pearson Correlation Sig. (2-tailed) N & $-0.392 * *$ & 1.000 \\
& & .000 & - \\
& & 125 & 125 \\
\hline
\end{tabular}

IV. CONCLUSION: PEDAGOGICAL IMPLICATIONS 
This experimental study has shown a negative correlation between FLLA and the subjects' listening achievement. Although FLLA is a complicated and multidimensional phenomenon, it is possible for us English teachers to find out the potential sources of FLLA and coping strategies.

First, as an instructor of listening, s/he needs to pay attention to the affective state of the learners, especially the listening anxiety experienced in listening so as to help improve the listening proficiency of the students. As the results of this research and many other researches have shown a negative relation between listening anxiety and listening performance, the listening instructors should "create a low-anxiety classroom atmosphere" as Young (1999) says.

Second, listening comprehension strategies are the particular approaches or techniques that learners use to try to reduce or lower students' listening anxiety and improve their listening comprehension ability (Ellis, 1994). According to the previous researches both at home and abroad, listening anxiety is negatively correlated to the use of listening comprehension strategies. That is to say, the more strategies students use during their listening process, the lower students' anxiety degree is. Therefore, English listening teachers should diagnose English learners' anxiety precisely and carry out corresponding strategies to improve students' listening level. To those highly anxious learners with low listening proficiency, the mastery of a variety of strategies and frequently using these strategies to handle anxiety is helpful in listening and learning. To those less anxious learners with high listening proficiency, using more strategies, integrating different strategies and raising the strategy awareness is helpful for them to make greater achievements.

Third, instructors should get rid of the teaching model which is just to play a record or cassette without giving any suggestions. As an instructor of listening, s/he should try to make his or her listening class interesting and rewarding so that a learner does not feel bored or tired about listening. For example, in listening classrooms, music, humorous stories and jokes, interesting narrative stories, deep breath training can be adopted as supplement to listening textbooks.

Fourth, students should be informed to be more autonomous and know their present level of foreign language learning. They should be faced with English listening anxiety and foreign learning problems objectively and correctly, and find appropriate strategies to lower anxiety and solve problems so as to improve their listening level and further improve their foreign language learning.

\section{APPENDIX 1}

TABLE 1

DESCRIPTIVE STATISTICS OF FLLAS

\begin{tabular}{|c|c|c|c|c|c|c|c|c|c|c|}
\hline $\begin{array}{l}\text { Anxiety } \\
\text { Items }\end{array}$ & 1 & 2 & 3 & 4 & 5 & Std.D & Mean & Maximum & Minimum & Valid N \\
\hline 1 & 7.6 & 28.9 & 27.2 & 28.5 & 7.8 & 1.10 & 2.99 & 5.00 & 1.00 & 125 \\
\hline 2 & 1.1 & 14.0 & 30.6 & 37.2 & 17.1 & .97 & 3.52 & 5.00 & 1.00 & 125 \\
\hline 3 & 0 & 10.6 & 17.2 & 53.9 & 18.3 & .86 & 3.8 & 5.00 & 2.00 & 125 \\
\hline 4 & 1.1 & 7.8 & 20.0 & 57.2 & 13.9 & .83 & 3.75 & 5.00 & 1.00 & 125 \\
\hline 5 & 0 & 26.7 & 30.0 & 38.9 & 4.4 & .89 & 3.21 & 5.00 & 2.00 & 125 \\
\hline 6 & 5.6 & 22.2 & 56.7 & 14.4 & 1.1 & .78 & 2.83 & 5.00 & 1.00 & 125 \\
\hline 7 & 10.0 & 30.6 & 23.3 & 30.6 & 5.6 & 1.11 & 2.91 & 5.00 & 1.00 & 125 \\
\hline 8 & 13.3 & 54.4 & 19.4 & 11.7 & 1.1 & .89 & 2.32 & 5.00 & 1.00 & 125 \\
\hline 9 & 1.1 & 9.4 & 17.2 & 49.4 & 22.8 & .92 & 3.83 & 5.00 & 1.00 & 125 \\
\hline 10 & 3.3 & 39.4 & 32.8 & 20.0 & 4.4 & .94 & 2.83 & 5.00 & 1.00 & 125 \\
\hline 11 & 8.9 & 33.9 & 21.7 & 30.0 & 5.6 & 1.10 & 2.89 & 5.00 & 1.00 & 125 \\
\hline 12 & 10.0 & 27.8 & 14.4 & 40.0 & 7.8 & 1.18 & 3.07 & 5.00 & 1.00 & 125 \\
\hline 13 & 5.6 & 18.9 & 26.7 & 37.2 & 11.7 & 1.08 & 3.31 & 5.00 & 1.00 & 125 \\
\hline 14 & 2.2 & 27.8 & 43.9 & 21.7 & 4.4 & .87 & 2.98 & 5.00 & 1.00 & 125 \\
\hline 15 & 1.1 & 23.9 & 30.0 & 39.4 & 5.6 & .92 & 3.24 & 5.00 & 1.00 & 125 \\
\hline 16 & 1.1 & 23.3 & 27.2 & 41.7 & 6.7 & .94 & 3.29 & 5.00 & 1.00 & 125 \\
\hline 17 & 3.3 & 36.7 & 31.7 & 26.1 & 2.2 & .92 & 2.87 & 5.00 & 1.00 & 125 \\
\hline 18 & 7.8 & 34.4 & 32.2 & 21.7 & 3.9 & 1.00 & 2.79 & 5.00 & 1.00 & 125 \\
\hline 19 & 0 & 21.7 & 20.0 & 51.7 & 6.7 & .90 & 3.43 & 5.00 & 2.00 & 125 \\
\hline 20 & 0 & 10.0 & 33.9 & 38.3 & 11.1 & 1.02 & 2.71 & 5.00 & 1.00 & 125 \\
\hline 21 & 11.7 & 52.2 & 23.9 & 12.2 & 0 & .84 & 2.37 & 4.00 & 1.00 & 125 \\
\hline 22 & 3.3 & 29.4 & 26.7 & 33.3 & 7.2 & 1.02 & 3.12 & 5.00 & 1.00 & 125 \\
\hline 23 & 5.6 & 50.6 & 21.7 & 17.8 & 4.4 & .98 & 2.65 & 5.00 & 1.00 & 125 \\
\hline 24 & 0 & 26.7 & 33.9 & 32.8 & 6.7 & .91 & 3.19 & 5.00 & 2.00 & 125 \\
\hline 25 & 11.7 & 54.4 & 28.9 & 5.0 & 0 & .73 & 2.27 & 4.00 & 1.00 & 125 \\
\hline 26 & 5.0 & 36.1 & 21.1 & 27.2 & 10.6 & 1.12 & 3.02 & 5.00 & 1.00 & 125 \\
\hline 27 & 2.2 & 8.9 & 17.8 & 55.6 & 15.6 & .91 & 3.73 & 5.00 & 1.00 & 125 \\
\hline 28 & 2.8 & 17.2 & 16.1 & 54.4 & 9.4 & .98 & 3.51 & 5.00 & 1.00 & 125 \\
\hline 29 & 3.3 & 29.4 & 31.1 & 27.8 & 8.3 & 1.02 & 3.08 & 5.00 & 1.00 & 125 \\
\hline 30 & 2.2 & 22.8 & 21.7 & 43.9 & 9.4 & 1.01 & 3.36 & 5.00 & 1.00 & 125 \\
\hline 31 & 11.1 & 36.7 & 16.1 & 28.3 & 7.8 & 1.18 & 2.85 & 5.00 & 1.00 & 125 \\
\hline 32 & 35.6 & 43.3 & 13.3 & 7.8 & 0 & .89 & 1.93 & 4.00 & 1.00 & 125 \\
\hline 33 & 13.3 & 42.2 & 18.9 & 20.0 & 5.6 & 1.11 & 2.62 & 5.00 & 1.00 & 125 \\
\hline 34 & 8.9 & 37.2 & 27.2 & 22.2 & 4.4 & 1.04 & 2.76 & 5.00 & 1.00 & 125 \\
\hline 35 & 9.4 & 33.3 & 28.3 & 24.4 & 4.4 & 1.05 & 2.81 & 5.00 & 1.00 & 125 \\
\hline
\end{tabular}




\section{APPENDIX 2}

\section{调查问卷}

亲爱的同学, 你好! 本问卷旨在了解当代大学生在大学英语教学中听力学习的情况, 以达到共同进步和提高 的目的, 无其他用途。请您认真阅读问卷中的每一道题目, 并根据自身的实际情况作答。所有问题的回答都是 一种主观判断, 没有“对”与“错”, “是”与“非”之分。本次调查是以匿名的形式进行的, 您的回答将处于完全保密 状态。为了保证本次调查结果的准确性, 请大家如实地回答所有的问题。

您的回答对于我们得出正确的结论很重要, 希望能得到您的配合和支持, 谢谢! 问卷上交后有一礼品奉送, 以表谢意。

\section{FLLAS (焦虑问卷)}

\section{学号:}

在你认为合适的选项下打勾, 以下为每个选项的意义, 表示你对这个表述的态度。

$1=$ 完全不同意 $2=$ 不同意 $3=$ 不确定 $4=$ 同意 $5=$ 完全同意

\begin{tabular}{|c|c|c|c|c|c|}
\hline 1. 听英语时我常常因为一两个生词而陷入困境。 & 1 & 2 & 3 & 4 & 5 \\
\hline 2. 英语听力测试时如果只读一遍我便很紧张。 & 1 & 2 & 3 & 4 & 5 \\
\hline 3. 听英语时我很难理解带有口音的英语。 & 1 & 2 & 3 & 4 & 5 \\
\hline 4. 当英语说得很快时, 我常常担心不能完全听懂。 & 1 & 2 & 3 & 4 & 5 \\
\hline 5. 如果听一个我不熟悉的话题, 我会很紧张。 & 1 & 2 & 3 & 4 & 5 \\
\hline 6. 我发现猜测我听的时候错过的部分是很容易的。 & 1 & 2 & 3 & 4 & 5 \\
\hline 7. 听英语的时候我不自信。 & 1 & 2 & 3 & 4 & 5 \\
\hline 8. 听英语的时候我常常最后在没有理解内容的情况下进行逐字翻译。 & 1 & 2 & 3 & 4 & 5 \\
\hline 9. 听英语的时候如果有些视觉提示 (诸如图片、视频和面部表情等), 我就会感到轻松些。 & 1 & 2 & 3 & 4 & 5 \\
\hline 10. 如果听的时候我稍微走一下神, 我就担心会错过重要的部分。 & 1 & 2 & 3 & 4 & 5 \\
\hline 11. 课堂上听英语如果没有文字材料我就感觉很不舒服。 & 1 & 2 & 3 & 4 & 5 \\
\hline 12. 当我听不懂老师的口头指令时我会很心烦。 & 1 & 2 & 3 & 4 & 5 \\
\hline 13. 听英语时我常常非常慌乱以致于记不得所听的内容。 & 1 & 2 & 3 & 4 & 5 \\
\hline 14. 听磁带而不是听人讲英语时我就会有信心。 & 1 & 2 & 3 & 4 & 5 \\
\hline 15. 听英语时我担心我对某些话题了解得不够充分。 & 1 & 2 & 3 & 4 & 5 \\
\hline 16. 听力考试时因为我几乎没有时间思考我所听到的内容所以很担心。 & 1 & 2 & 3 & 4 & 5 \\
\hline 17. 听英语时我的思绪常常很乱。 & 1 & 2 & 3 & 4 & 5 \\
\hline 18. 我一直认为除了我别人都很理解要听的内容。 & 1 & 2 & 3 & 4 & 5 \\
\hline 19. 如果一个人讲英语的时候很平静, 我就担心理解的问题。 & 1 & 2 & 3 & 4 & 5 \\
\hline 20. 当听人在电话里说英语时, 我就会很紧张。 & 1 & 2 & 3 & 4 & 5 \\
\hline 21. 听英语讲座时我感觉很轻松。 & 1 & 2 & 3 & 4 & 5 \\
\hline 22. 当有一些背景噪音我就很难听懂英语。 & 1 & 2 & 3 & 4 & 5 \\
\hline 23. 听英语时碰到一些我不理解的词我也不会受到干扰。 & 1 & 2 & 3 & 4 & 5 \\
\hline $\begin{array}{l}\text { 24. 听英语时我常常能几乎听懂每一个单词的意义, 但是依然不能很好的理解说话者所说的内 } \\
\text { 容。 }\end{array}$ & 1 & 2 & 3 & 4 & 5 \\
\hline 25. 我喜欢听英语。 & 1 & 2 & 3 & 4 & 5 \\
\hline 26. 学习英语最难的就是听喠口语。 & 1 & 2 & 3 & 4 & 5 \\
\hline 27. 我对我目前所达到的英语听力水平很满意。 & 1 & 2 & 3 & 4 & 5 \\
\hline 28. 独自一人听英语比集体听英语我感觉更轻松一些。 & 1 & 2 & 3 & 4 & 5 \\
\hline 29. 我似乎对英语文化和思想很陌生。 & 1 & 2 & 3 & 4 & 5 \\
\hline 30. 听英语的时候一碰到复杂的结构我就心烦。 & 1 & 2 & 3 & 4 & 5 \\
\hline 31. 我不介意老师或同学对我的听力水平进行评判。 & 1 & 2 & 3 & 4 & 5 \\
\hline 32. 我不喜欢上我们的英语听力课。 & 1 & 2 & 3 & 4 & 5 \\
\hline 33. 上听力课我常常开小差。 & 1 & 2 & 3 & 4 & 5 \\
\hline 34. 我总是担心我听力考试会不过关。 & 1 & 2 & 3 & 4 & 5 \\
\hline 35. 期末听力考试我一点都不紧张。 & 1 & 2 & 3 & 4 & 5 \\
\hline
\end{tabular}

\section{REFERENCES}

[1] Aida, Y. (1994). Examination of Horwitz, Horwitz, and Cope's construct of Foreign language anxiety: The case of students of Japanese. The Modern Language Journal, 78 (2), 155-168.

[2] Chen, Xiuling. (2004). English listening comprehension and anxiety. Computer-Assisted Foreign Language Education. 96,65-72.

[3] Cohen, A. D. (2005). Strategies in learning and using a second language. Beijing: Foreign Language Teaching and Research Press.

[4] Elkhafaifi, H. (2005). Listening Comprehension and Anxiety in the Arabic Language Classroom. The Modern Language Journal, 89, 206-220.

[5] Ellis, R. (1994). The study of second language acquisition. Oxford: Oxford University Press. 
[6] Horwitz, E. K., Horwitz, M. B., \& Cope, J. (1986). Foreign language classroom anxiety. The Modern Language Journal, 70 (2), $125-132$.

[7] Kim, J. H. (2000). Foreign language listening anxiety: A study of Korean students learning English. Unpublished doctoral dissertation, University of Texas, Austin.

[8] MacIntyre, P. D. (1999). Language anxiety: A review of the research for language teachers. In D. J. Young (Ed.), Affect in foreign language and second language learning: A practical guide to creating a low-anxiety classroom atmosphere. (pp.24-45). Boston: McGraw-Hill.

[9] Young, D. J. (1992). Language anxiety from the foreign language specialist's perspective: Interactive with Krashen, Omagggio Hadley, Terrell, and Rubin. Foreign Language Annuals, 25, 157-172.

[10] Young, D. J. (1999). A perspective on foreign language learning: From body to mind to emotions. In D.J. Young (Ed.) Affect in foreign language and second language learning: A practical guide to creating a low-anxiety classroom atmosphere. (pp.13-23). Boston: McGraw-Hill.

[11] Zhou, Dandan. (2003). Listening anxiety and affective strategies the in second language classroom. Foreign Language Teaching Abroad. 3,56-58.

Shengli Wang was born in Suiping, Henan Province, China in 1970. He received his M.A. degree in applied linguistics from Zhengzhou University, China in 2002.

$\mathrm{He}$ is currently an associate professor in the School of Foreign Studies, Henan Agricultural University, Zhengzhou, China. His research interests include contrastive linguistics and second language acquisition. 